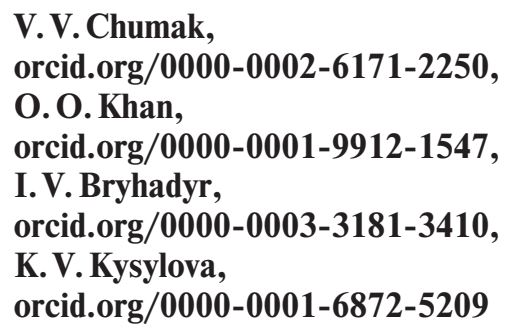

Kharkiv National University of Internal Affairs, Kharkiv, Ukraine, e-mail: aa khan@ukr.net

\title{
PROTECTION OF THE SUBSOIL OF THE CONTINENTAL SHELF OF UKRAINE BY INTERNATIONAL AND NATIONAL INSTRUMENTALITIES
}

Purpose. Identification of international and national mechanisms for protection of the subsoil of the continental shelf of Ukraine and provision of scientifically sound recommendations for improving the legal regulation of their application.

Methodology. During the study, the dialectical method was used - to learn the essence of such a phenomenon as the protection of the subsoil of the continental shelf; the system-structural method - when analyzing objective and subjective features of the crime under Part 2 of Art. 244 of the Criminal Code of Ukraine; the comparative-and-legal method - in the study on the sanction of Part 2 of Art. 244 of the Criminal Code of Ukraine; the logical and dogmatic method - when developing recommendations for improving legal norms.

Findings. As a result of the study, mechanisms of protection of the continental shelf of Ukraine were determined. The necessity of improvement of the legislative base regulating the order of their realization is proved.

Originality. The international legal and national mechanisms of state protection of the continental shelf of Ukraine are determined. In order to improve the state protection of the continental shelf, legislative changes to Part 1 of Art. 26 of the Subsoil Code of Ukraine, Part 2 of Art. 244 of the Criminal Code of Ukraine and Part 2 of Art. 216 of the Criminal Procedure Code of Ukraine are suggested.

Practical value. Proposals to improve the current legislation of Ukraine are presented aimed at improving the efficiency of the State Service of Geology and Subsoil of Ukraine, the National Police, the Security Service of Ukraine and the judiciary to protect the subsoil of the continental shelf of Ukraine from illegal use by foreign companies.

Keywords: continental shelf of Ukraine, subsoil protection, international and national protection mechanism, international, administrative and criminal liability

Introduction. According to certain studies, the Ukrainian shelf of the Black and Azov Seas, which covers an area of 133.7 thousand $\mathrm{km}^{2}$, can fully assure Ukraine's needs for gas and partly for oil. According to the State Service of Geology and Subsoil of Ukraine, the potential reserves of energy resources (oil and natural gas) on the Ukrainian Black Sea shelf are estimated at 2.3 billion tons of conventional fuel (equivalent to 2.3 trillion $\mathrm{m}^{3}$ ), which is about $40 \%$ of all energy reserves of our country. These reserves are distributed as follows: north-western shelf -604.1 million tons of nominal fuel; deep-water basin of the Black Sea - 346.0 million tons; Prykerchenskyi shelf -257.0 million tons; water area of the Sea of Azov - 324.8 million tons. Other small-scale reserves have been discovered in other parts of the Ukrainian shelf of the Black and Azov Seas. Significant reserves of energy resources have been discovered in the area of Kilim (250485 billion $\mathrm{m}^{3}$ of natural gas), the Scythian section ( 35 billion $\mathrm{m}^{3}$ of gas and 25-60 million tons of oil), the Nakhimov structure ( 29 billion $\mathrm{m}^{3}$ of gas), the Kornilov structure (35 billion $\mathrm{m}^{3}$ of gas), Ahib's structure (6.7 million tons of oil) [1].

The energy resources of the continental shelf are important for the economy of Ukraine and their protection is a strategic task of the state to ensure the economic security as part of the national security. In this regard, there is a need to study the existing mechanisms of state protection of the resources of the continental shelf and provide scientifically grounded proposals for their improvement.

Literature review. The continental shelf of Ukraine, the order of its use and protection were studied by such researchers in the field of environmental law as: O. Vysotsky, O. V. Chornous, S. V. Molodtsov, Y. I. Bistrakov, O.S. Babyak, P. D. Bilenchuk, S.A. Balashenko, D. M. Demichev, A.P. Hetman, V.K. Popov, M.V.Shulga, O.S. Kolbasov, V.V. Kostitsky, V.V.Petrov, and others. Among researchers of problems of

(c) Chumak V.V., Khan O. O., Bryhadyr I. V., Kysylova K. V., 2021 criminal liability for illegal actions on the continental shelf of Ukraine made by foreigners, the issues have become the subject of research by such scientists as S. B. Gavrish, M. I. Melnyk, A. M. Richelyuk, M. I. Khavronyuk, O. O. Dudorov. At the same time, the research of these scientists raised new questions in the problems of protection of the subsoil of the continental shelf of Ukraine and the need for new scientific research.

The problems of improving the mechanisms of administrative and criminal counteraction to illegal use of the subsoil of the continental shelf by foreign individuals and legal entities remain unresolved.

Purpose. Identification of international and national mechanisms for the protection of the subsoil of the continental shelf of Ukraine and the provision of scientifically grounded recommendations for improving the legal regulation of their implementation. The purpose of the study is achieved by performing the following tasks:

- analysis of literature sources and legal acts, which describe and regulate the existing state mechanisms for the protection of the subsoil of the continental shelf of Ukraine from their illegal use by foreign persons;

- study on the legally defined mechanism of activity of the State Service of Geology and Subsoil of Ukraine as a subject of counteraction to illegal use of subsoil of the continental shelf of Ukraine and provision of proposals for its improvement;

- study on criminal acts under Part 2 of Art. 244 of the Criminal Code of Ukraine, a subject of this crime, providing their doctrinal interpretation;

- conducting a comparative analysis of the punishment for illegal work of foreign persons on the continental shelf, in particular in the extraction of minerals, and the degree of public danger of this crime, providing scientific proposals for their harmonization on this basis;

- study on the problem of investigation of crimes under Part 2 of Art. 244 of the Criminal Code of Ukraine. 
Methods. The methodological basis of the study is a system of general and special methods of cognition. The dialectical method was used to learn the essence of such a phenomenon as the protection of the subsoil of the continental shelf. The system-structural method was used in the analysis of objective and subjective features of the crime under Part 2 of Art. 244 of the Criminal Code of Ukraine. The logical-dogmatic method of research was used in the interpretation of certain terms used in the sciences of geology, administrative and criminal law and contained in the provisions of current legislation, as well as in formulating definitions of legal concepts and developing recommendations for improving the rules of Part 1 of Art. 26 of the Subsoil Code of Ukraine, Part 2 of Art. 244 of the Criminal Code of Ukraine, Part 2 of Art. 216 of the Criminal Procedure Code of Ukraine. The comparative legal method was used in the study on the sanction of Part 2 of Art. 244 of the Criminal Code of Ukraine for its compliance with the degree of public danger of this crime. General methods (analysis, synthesis, induction, deduction, abstraction, generalization) were used in the study on scientific and regulatory sources. Statistical methods were used during the analysis of official statistical reporting of law enforcement and judicial bodies under Part 2 of Art. 244 of the Criminal Code of Ukraine.

Results. In geology, the continental shelf is considered as a part of the land flooded by the sea, located on the periphery of the continent, a large continental shoal (flooded edge of the continent), which is an underwater extension of the continent to the geomorphological line of its transition to a steep slope [2].

The legal definition of the continental shelf is somewhat different from the general scientific one. This should be linked to an attempt to reflect in a formal sense of the term the criteria for demarcating a territory that is a continental shelf and belongs to a particular country in order to balance the rights of border maritime countries to use its natural resources.

The Geneva Convention on the Continental Shelf of 1958 refers to this concept: 1) the surface and subsoil of the seabed of underwater areas adjacent to the shore, but located outside the territorial sea zone, to a depth of $200 \mathrm{~m}$, or outside this boundary to a spot where the depth of covering waters allows development of natural resources of these areas; 2) the surface and subsoil of such underwater areas adjacent to the shores of the islands. It can be seen that the criteria for determining the outer boundary of the shelf here are: adjacency to the coast, sea depth of $200 \mathrm{~m}$ and suitability for operation of underwater areas [3].

Subsequently, the international legal definition of the concept of the continental shelf has undergone transformations. The 1982 United Nations Convention on the Law of the Sea defined that the continental shelf is the seabed and subsoil of submarine areas extending beyond the territorial sea throughout the natural extension of its land area to the outer boundary of the mainland or 200 nautical miles from the mainland source lines, from which the width of the territorial sea is calculated, when the outer boundary of the underwater edge of the mainland does not extend to such a distance [4].

The 1958 UN Convention on the Continental Shelf and the 1982 UN Convention on the Law of the Sea defined the sovereign rights of coastal states within their continental shelf for the exploration and development of the latter's natural resources. The sovereign rights of a coastal country mean not only the right to explore and develop the natural resources of the continental shelf, but also correspond to the obligation of other countries to refrain from such actions without the consent of the continental shelf owner, as well as to refrain from claims to its continental shelf.

With the annexation of the Crimean peninsula by the Russian Federation, the territory of the continental shelf of Ukraine has decreased threefold (from 130 to almost 40 thousand square kilometers). Ukraine has lost gas fields on the Black Sea shelf near the Crimean peninsula. Resources in the north-western part of the Black Sea shelf are estimated at
495.7 billion cubic meters of natural gas and 50.4 million tons of oil and condensate, the Prykerchensky zone -321.2 billion cubic meters and 126.8 million tons of oil and condensate, continental slope -766.6 billion cubic meters of natural gas and 232.6 million tons of oil and condensate [5].

According to Chornomornaftogaz, the Russian Federation has extracted 7.2 billion cubic meters of natural gas on the occupied peninsula and shelf of the Black and Azov Seas since the annexation and 222.6 thousand tons of gas condensate and oil. In 2014, 2 billion cubic meters of gas was extracted and 57.1 thousand tons of gas condensate and oil, in 2015 1.84 billion cubic meters of natural gas, 61.1 thousand tons of gas condensate and oil, in $2016-1.67$ billion cubic meters of gas and 53.4 thousand tons of gas condensate and oil, in $2017-1.62$ billion cubic meters of gas and 51 thousand tons of gas condensate and oil. In 2014-2015, the Russian Federation illegally drilled 7 wells at the Odesa field [6].

On September 14, 2016 Ukraine initiated arbitration proceedings against the Russian Federation in accordance with the 1982 UN Convention on the Law of the Sea to protect its rights in the Black and Azov Seas and the Kerch Strait. The Ukrainian government states that Russia, as an aggressor state, has violated Ukraine's rights to the natural resources of the Crimean continental shelf and continues to do so. Ukraine requests the arbitral tribunal to confirm its rights as a coastal state and to oblige the Russian Federation to cease internationally illegal acts in the relevant maritime waters, to provide Ukraine with appropriate assurances and guarantees of their non-recurrence, and to reimburse Ukraine for all damages caused by the Russian Federation [7].

The second international arbitration process against the Russian Federation was initiated in October 2016 by Naftogaz of Ukraine together with six other companies of the group (Chornomornaftogaz, Ukrtransgaz, Ukrgazvydobuvannya, Ukrtransnafta, Gaz Ukrainy, Likvo) and considered in the Permanent Court of Arbitration in The Hague in accordance with the UNISTRAL Regulation of 1976. Naftogaz of Ukraine demands to reimburse $\$ 7$ billion of interest-bearing losses [8].

The international mechanism for the protection of the continental shelf and its natural resources, established by the 1982 United Nations Convention on the Law of the Sea, provides for the possibility of prosecuting a State in violation of the Convention. Such liability is material (compensatory) and political.

Among the national means of protection of the property of the Ukrainian people for the natural resources of the continental shelf, administrative and criminal remedies should be distinguished.

The first national method is regulated by Art. 56 and 57 of the Subsoil Code of Ukraine and consists in giving the State Service of Geology and Subsoil of Ukraine (the central executive body implementing the state policy in the field of geological study and rational use of subsoil) powers to restrict, temporarily prohibit (stop) or stop subsoil use in case of violation by the subjects of subsoil use of the procedure established by law for the provision of subsoil for use or unauthorized use of subsoil. Today, the Subsoil Code of Ukraine provides the possibility of using subsoil only on the basis of a special permit: "Art. 19. Subsoil shall be provided for use to enterprises, institutions, organizations and citizens only if they have a special permit for the use of the subsoil area. The right to use subsoil is certified by an act on granting a mining allotment". This norm concerns the issue of providing subsoil for use by national users. With regard to foreigners, stateless persons and foreign legal entities, a slightly different rule is provided: "Art. 68. Foreigners and stateless persons, foreign legal entities are granted subsoil use and the right to process mineral raw materials on a competitive basis on the basis of agreements (contracts) concluded in accordance with the requirements of this Code and other legislative acts of Ukraine". So, we have different procedures for providing subsoil use for national and foreign entities. 
The mechanism for exercising the powers of the State Service of Geology and Subsoil of Ukraine for the forced cessation of subsoil use, according to Art. 26 of the Subsoil Code of Ukraine is defined as follows: the right to use subsoil is terminated by the body that provided subsoil for use, and in cases provided for in paragraphs $4,5,6$ of this article, in case of disagreement of users - in court. The body that provided the subsoil for use, respectively, is the State Service of Geology and Subsoil of Ukraine. Regarding the cases provided for in paragraphs 4, 5, 6 of Art. 26 of the Subsoil Code of Ukraine, they are reduced to the following cases: 1) if the subsoil is used involving methods and techniques that adversely affect the state of the subsoil, lead to environmental pollution or harmful effects on public health; 2) in case of use of subsoil not for the purpose for which they were provided, violation of other requirements provided by the special permission for use of the subsoil area; 3 ) if the user have not started using the subsoil without valid reasons within two years, and for oil and gas promising areas and fields of oil and gas -180 calendar days.

Analysis of the content of these cases indicates the legal uncertainty of the situation when the subsoil is used arbitrarily. This circumstance does not fall under any of the conditions described in the law. All the described conditions apply to situations when the business entity has already received a subsoil use permit, but does not use this right or uses it in violation.

In this regard, we see it appropriate to amend the legislation in this part and provide for the right of the State Service of Geology and Subsoil of Ukraine to apply to the court for the forced cessation of arbitrary subsoil use, i.e. one that is carried out without special permission (for national entities) or agreements (for foreign entities). In this regard, we propose to supplement Part 1 of Art. 26 of the Subsoil Code of Ukraine paragraph 61 of the following content: "61) in the case of subsoil use without a special permit or agreement (contract)". In this case, the State Service of Geology and Subsoil of Ukraine, having a court decision on the obligation to terminate the use of subsoil will be able to enforce it under the Law of Ukraine "On Enforcement Proceedings" with the involvement of the State Enforcement Service of Ukraine and the National Police.

The second national means of protection of subsoil from arbitrary use is that the current Criminal Code of Ukraine (Article 2, Article 244) provides criminal liability for research, exploration, development of natural resources and other work on the continental shelf of Ukraine, carried out by foreigners, unless it is provided by an agreement between Ukraine and the interested foreign state, the consent to the binding nature of which is given by the Verkhovna Rada of Ukraine or a special permit issued in the manner prescribed by law. For committing this crime there is an alternative penalty in the form of a fine of two thousand to five thousand non-taxable minimum incomes or arrest for up to six months.

In contrast to the international legal responsibility under the 1982 UN Convention on the Law of the Sea, to which the state is a subject, criminal liability arises for individualized individuals - foreigners (citizens of other countries).

According to the Prosecutor General's Office of Ukraine since the occupation of the Crimea by the Russian Federation and the Black Sea and Azov continental shelves, respectively, only one criminal proceeding has been registered in Ukraine under Art. 244 of the Criminal Code of Ukraine (in 2016) [9]. However, since gas and oil companies of the Russian Federation already illegally extract resources from the subsoil of the continental shelf of Ukraine, there is a problem of legal liability not only of the Russian Federation as a state, but also criminal liability of specific citizens of this state or other foreigners activity. Thus, the need to protect the subsoil of the continental shelf of Ukraine today is primarily related to the actions of the Russian Federation as an aggressor state in the temporarily occupied territory of Ukraine in the Autonomous Republic of Crimea and its continental shelf in this part.
In this regard, we consider it necessary to provide a criminal description of the crime under Part 2 of Art. 244 of the Criminal Code of Ukraine in order to provide scientific advice on its proper qualification by law enforcement agencies of Ukraine to further combat the illegal extraction of minerals on its continental shelf.

Disposition of Part 2 of Art. 244 of the Criminal code of Ukraine is stated by the legislator as follows: "Research, exploration, development of natural resources and other works on the continental shelf of Ukraine which are carried out by foreigners if it is not provided by the agreement between Ukraine and the interested foreign state, the binding nature of which has been approved by the Verkhovna Rada of Ukraine or a special permit issued in the manner prescribed by law".

The socially dangerous act of this crime is expressed in such alternative actions as: 1) research on natural resources on the continental shelf of Ukraine; 2) exploration for natural resources on the continental shelf of Ukraine; 3) development of natural resources on the continental shelf of Ukraine; 4) other works on the continental shelf of Ukraine. The obligatory sign of criminality of these actions is that their commission is not provided by the agreement between Ukraine and the interested foreign state, the consent to which is obligatory given by the Verkhovna Rada of Ukraine or the special permission issued in the order established by law.

As can be seen from the description of the socially dangerous act of this crime, in part this disposition is a banquet. The legislator directly defines such criminal acts as research, exploration and development of natural resources of the continental shelf of Ukraine, but leaves uncertain the range of other types of work that, given their illegality, can be considered a crime. The subject of this crime, which is defined as "natural resources of the continental shelf", is not specified by the legislator, which requires disclosure of the meaning of this concept. It is also necessary to define the concept and procedure for concluding international agreements with another state or issuing a special permit for exploration, development or other work on the continental shelf of Ukraine.

For the correct criminal-legal qualification it is also important to have a correct understanding of the possible subject composition of this crime through the coverage of the meaning of the concept of "foreigners" provided in the criminallegal doctrine.

The concept of the subject of this crime (natural resources of the continental shelf) is contained in the UN Convention on the Continental Shelf of 1958, according to which they are mineral and other inanimate resources of the seabed and its subsoil, as well as living organisms belonging to "sedentary species" that is, those that are in a stationary state on or under the seabed during the fishery, or are unable to move other than by being in constant contact with the seabed or its subsoil. From this definition it can be seen that the subject of the crime is wider than the natural resources of the subsoil of the continental shelf. Let us dwell in more detail on the problems of criminal law protection of the subsoil of the continental shelf.

Regarding the concept of research on natural resources on the continental shelf of Ukraine, its definition at the legislative level is missing. As part of the study on the subsoil of the continental shelf in the Law of Ukraine "On Oil and Gas" of July 12, 2001 No. 2665-III uses the concept of "geological study on oil and gas subsoil", which means a set of works to study the geological structure and oil and gas certain area, including geological survey, geophysical, geochemical, aerocosmogeological research, direct exploration, drilling and testing of wells, research and development, research and thematic work, their analysis and generalization.

It is noteworthy that the categories of exploration and development of the continental shelf, which are used by the legislator in describing the socially dangerous act provided for in Part 2 of Art. 244 of the Criminal Code of Ukraine are borrowed from the provisions of the 1958 UN Convention on the Continental Shelf. 
Law of Ukraine "On Oil and Gas" in Art. 1 provides a definition of these concepts, where exploration work is geological surveying, exploration, geodetic work, work on geological study on oil and gas, subsoil exploration and exploration, including drilling, installation and operation of oil and gas wells, new construction, maintenance, overhaul and reconstruction of oil and gas wells and related to their maintenance of pipeline transport facilities, production facilities, access roads, power lines and communications. Oil and gas field development is a technological process of extracting oil, gas and related useful components from a field, which consists of two successive stages - experimental and industrial development of the field and industrial development of the field.

Other works on the continental shelf, in addition to exploration and development, are regarded in the professional literature as the commercial cultivation of products, their processing, transportation, construction, reconstruction or repair of installations and structures, and so on [10].

Thus, from the point of view of the legislation, any work carried out by foreigners on the continental shelf of Ukraine is criminally punishable, unless they are provided for by an international agreement with Ukraine or a special permit has been issued for such work. In this regard, it is necessary to determine the procedure for concluding international agreements for foreigners to work on the continental shelf of Ukraine and the procedure for issuing special permits for this activity.

According to Art. 3 of the Law of Ukraine "On International Agreements of Ukraine", international agreements on the use of territory and natural resources of Ukraine are concluded by the President of Ukraine or on his order on behalf of Ukraine.

As already mentioned, according to Art. 68 of the Subsoil Code of Ukraine, subsoil for use and the right to process mineral resources are provided to foreigners and stateless persons, foreign legal entities on a competitive basis on the terms of agreements (contracts) concluded in accordance with the requirements of this Code and other legislation of Ukraine. Thus, foreigners receive the use of the subsoil of the continental shelf on the basis of agreements (contracts), rather than a special permit. This indicates a conflict in legislation between Art. 68 of the Subsoil Code of Ukraine and Part 2 of Art. 244 of the Criminal Code of Ukraine. To overcome the conflict, we propose to harmonize these rules by amending the disposition of Part 2 of Art. 244 of the Criminal Code of Ukraine, replacing a phrase "... the special permission issued in the order established by the law" with "... the agreement (contact) concluded with the authorized state body in the order established by the law".

The subject of this crime is foreigners. This concept in item 5 of h. 1 Art. 1 of the Law of Ukraine "On the legal status of foreigners and stateless persons" means persons who are not citizens of Ukraine and are citizens (subjects) of another state or states.

The commission of this crime is punishable by a fine of two thousand to five thousand non-taxable minimum incomes or arrest for up to six months. It is known that the type and measure of punishment is a criterion for classifying crimes into minor, serious and especially serious. In accordance with Part 4 of Art. 12 of the Criminal Code of Ukraine, the crime for commission of which the basic punishment in the form of a penalty of no more than ten thousand non-taxable minimum incomes of citizens or imprisonment for a term no more than five years is provided is recognized as not serious. Thus, according to the legislator, the crime under Part 2 of Art. 244 of the Criminal Code of Ukraine is not difficult. This raises the question of whether the type and measure of punishment correspond to the level of public danger of the crime. After all, according to the Constitution of Ukraine (Article 13), the subsoil and natural resources of the continental shelf are objects of property rights of the Ukrainian people. Although the Basic Law does not state that the subsoil and natural resources of the continental shelf are under special state protection, as stated in relation to land (Article 14), it should be stated that their protection is no less important for Ukraine. And those actions that are committed today by foreigners (especially citizens of the Russian Federation) cannot be described as having no serious consequences for Ukraine, because they undermine the economic security of the country due to the loss of its resource potential.

In this regard, we propose to increase the penalty for this crime, providing for a fine of 15 to 20 thousand tax-free minimum incomes or imprisonment for a term of 6 to 8 years. In this case, this crime receives the classification status of a serious crime, which in our opinion will be more in line with its degree of public danger. To do this, the sanctions of Part 2 of Art. 244 of the Criminal Code of Ukraine should be replaced the words "... a fine of two thousand to five thousand non-taxable minimum incomes or arrest for up to six months" with the words "... a fine of fifteen to twenty thousand non-taxable minimum incomes or imprisonment for term from 6 to 8 years".

The controversial approach of the legislator to the assignment of criminal proceedings under Part 2 of Art. 244 of the Criminal Code of Ukraine under the jurisdiction of the $\mathrm{Na}$ tional Police is worthy of separate attention. It has already been noted that the protection of the subsoil of the continental shelf and its other natural resources is of strategic economic importance for Ukraine, in particular, it is a guarantor of its energy independence. Today, the function of protection of economic security of Ukraine is legally endowed with another state body - the Security Service of Ukraine. In particular, according to Part 2 of Art. 2 of the Law of Ukraine "On the Security Service of Ukraine", its tasks include the prevention, detection, cessation and detection of crimes against organized crime in the economy, which directly threaten the vital interests of Ukraine. In fact, the crimes currently committed by foreigners - representatives of gas and oil companies of the Russian Federation under Part 2 of Art. 244 of the Criminal Code of Ukraine by subject composition are organized criminal acts aimed at causing significant harm not only to the environment but also to the economic interests of Ukraine. The National Police, by its functional purpose, have a more inherent function of counteracting criminal offenses of violating public safety and order, personal rights of citizens, etc., which are also referred to as "crimes of a general criminal nature". To address this issue, i.e. the transfer of powers to investigate illegal work on the continental shelf of Ukraine by foreigners from the jurisdiction of the National Police to the jurisdiction of the Security Service of Ukraine, it is proposed to supplement Part 2 of Art. 216 of the Criminal Procedure Code of Ukraine after the figure "2011" in words and the figure "part 2 of Article 244". To do this, it is proposed to supplement Part 2 of Art. 216 of the Criminal Procedure Code of Ukraine after the figure "2011" in words and the figure "part 2 of Article 244".

This position is also substantiated by the complexity of operational-search and investigative (search) actions in this category of crimes, as they are committed in the territory which is not under the control of Ukraine. It is seen that the Security Service of Ukraine itself has a significant intelligence network, whose staff has the skills and necessary technical equipment to secretly obtain information about crimes and its participants in the uncontrolled territory.

Conclusions. Summarizing the above, we should note that the state protection of the subsoil of the continental shelf of Ukraine from illegal encroachments occupies a special place in the system of economic and national security of Ukraine from external threats from foreign countries. Current international and national legislation offers a number of mechanisms to combat the illegal seizure of the continental shelf and its natural resources: international law, administrative law and criminal law. The complexity of their implementation is due to the active resistance of the authorities and law enforcement agencies of the aggressor country and the imperfection of national legislation. However, appropriate scientific recommendations for the implementation of national mechanisms should be formed today. The proposed amendments to the current 
legislation of Ukraine will help intensify the activities of authorized state bodies to prosecute for illegal actions on the continental shelf of Ukraine.

\section{References.}

1. Development of the Black Sea shelf: competition and cooperation (2020). Retrieved from https://dgs.kiev.ua/news galuz/273-osvoyennya-chornomorskogo-shelfu-konkurencya-ta-spvpracya.html.

2. Povko, V. (2016). Legal ambushes for the distribution of the continental shelf in the polar region: problems and theories and practice. Bulletin of the Ministry of Justice of Ukraine, 1(171), 52. 3. Convention on the Continental Shelf of 29.04.1958 (2020). Retrieved from https://zakon.rada.gov.ua/laws/ show/995 179\#Text.

4. Convention on the Sea Law of 10.12.1982 (2020). Retrieved from https://zakon.rada.gov.ua/laws/show/995 057\#Text.

5. Kyryliuk, O. (2018). Gas reserves in the areas of the Black Sea shelf controlled by Ukraine amount to almost 37 billion cubic meters, on the shelf of Azov - about 10 billion cubic meters. Retrieved from https://censor.net.ua/ua/news/3081540/ zapasy_gazu_na_dilyankah_chornomorskogo_shelfu_pidkontrolnyh ukrayini stanovlyat mayije $37 \mathrm{mlrd}$ kub.

6. Niezhnova, S. (2018). It is possible that Russia is already preparing to return to Ukraine previously selected deposits on the Black Sea shelf: an interview with the head of "Chornomornaftogaz” Svetlana Nezhnova. Retrieved from https://ua.112.ua/ interview/ne-vykliucheno-shcho-rf-vzhe-hotuietsia-povernuty-ukraini-vidibrani-ranishe-rodovyshcha-na-shelfi-chornoho-moria-434858.html/.

7. Chabai, H. (2019). Prove Russian aggression in court. Retrieved from https://tyzhden.ua/Politics/237167.

8. European truth (2016). Ukraine has filed a lawsuit against Russia in the UN International Tribunal for the Law of the Sea. Retrieved from https://www.eurointegration.com.ua/ news/2016/09/14/7054563/.

9. Prosecutor General's Office of Ukraine (2020). Statistical information on registered criminal offenses for 2011-2020. Retrieved from https://old.gp.gov.ua/ua/statinfo.html.

10. Melnyk, M. I., \& Khavroniuk, M. I. (Eds.) (2018). Scientific and practical commentary on the Criminal Code of Ukraine (10 $10^{\text {th }}$ ed.). Kyiv:VD "Dakor".

\section{Охорона надр континентального шельфу України міжнародними та національними засобами}

\section{В. В. Чумак, О. О. Хань, І. В. Бригадир, К. В. Кисильова}

Харківський національний університет внутрішніх справ, м. Харків, Україна, е-mail: aa_khan@ukr.net

Мета. Визначення міжнародних і національних механізмів охорони надр континентального шельфу України та надання науково обгрунтованих рекомендацій щодо вдосконалення нормативно-правового регулювання їх застосування.

Методика. Під час дослідження застосовувався діалектичний метод - для пізнання сутності такого явища як охорона надр континентального шельфу; системноструктурний - при здійсненні аналізу об'єктивних і суб'єктивних ознак складу злочину, передбаченого ч. 2 ст. 244 Кримінального кодексу України; порівняльно-правовий - при дослідженні санкції ч. 2 ст. 244 Кримінального кодексу України; логіко-догматичний - при розробці рекомендацій щодо вдосконалення юридичних норм.

Результати. У результаті проведеного дослідження визначені механізми охорони континентального шельфу України. Доведена необхідність удосконалення законодавчої бази, що регламентує порядок їх реалізації.
Наукова новизна. Визначені міжнародно-правовий і національний механізми охорони континентального шельфу України як державні. 3 метою удосконалення державної охорони континентального шельфу запропоновані законодавчі зміни до ч. 1 ст. 26 Кодексу України про надра, ч. 2 ст. 244 Кримінального кодексу України та ч. 2 ст. 216 Кримінального процесуального кодексу України.

Практична значимість. Надані пропозиції щодо удосконалення чинного законодавства України, спрямовані на підвищення ефективності діяльності Державної служби геології та надр України, Національної поліції, Служби безпеки України та судових органів щодо охорони надр континентального шельфу України від незаконного користування ними іноземними компаніями.

Ключові слова: континентальний шельф України, охорона надр, міжнародний і національний механізм охорони, міжнародна, адміністративна та кримінальна відповідальність

\section{Охрана недр континентального шельфа Украины международными и национальными средствами}

\section{В. В. Чумак, А. А. Хань, И. В. Бригадир, К. В. Кисилёва}

Харьковский национальный университет внутренних дел, г. Харьков, Украина, e-mail: aa khan@ukr.net

Цель. Определение международных и национальных механизмов охраны недр континентального шельфа Украины и предоставление научно обоснованных рекомендаций по совершенствованию нормативно-правового регулирования их применения.

Методика. В ходе исследования применялся диалектический метод - для познания сущности такого явления как охрана недр континентального шельфа; системно-структурный - при осуществлении анализа объективных и субъективных признаков состава преступления, предусмотренного ч. 2 ст. 244 Уголовного кодекса Украины; сравнительно-правовой - при исследовании санкции ч. 2 ст. 244 Уголовного кодекса Украины; логико-догматический - при разработке рекомендаций по совершенствованию юридических норм.

Результаты. В результате проведенного исследования определены механизмы охраны континентального шельфа Украины. Доказана необходимость усовершенствования законодательной базы, регламентирующей порядок их реализации.

Научная новизна. Определены международно-правовой и национальный механизмы охраны континентального шельфа Украины как государственные. С целью усовершенствования государственной охраны континентального шельфа предложены законодательные изменения в ч. 1 ст. 26 Кодекса Украины о недрах, ч. 2 ст. 244 Уголовного кодекса Украины и ч. 2 ст. 216 Уголовно-процессуального кодекса Украины.

Практическая значимость. Представлены предложения по совершенствованию действующего законодательства Украины, направленные на повышение эффективности деятельности Государственной службы геологии и недр Украины, Национальной полиции, Службы безопасности Украины и судебных органов по охране недр континентального шельфа Украины от незаконного пользования ими иностранными компаниями.

Ключевые слова: континентальный шельф Украины, охрана недр, международный и национальный механизм охраны, международная, административная и уголовная ответственность

Recommended for publication by K. L. Buhaichuk, Doctor of Legal Sciences. The manuscript was submitted 06.08.20. 